\title{
PENGEMBANGAN KOTARA (KOMIK CERITA RAKYAT) "ASAL MULA DESA ALIANTAN" UNTUK SISWA SEKOLAH DASAR
}

\author{
Silvia Eka Putri ${ }^{1}$, Otang Kurniaman ${ }^{2}$ \\ ${ }^{1,2}$ Universitas Riau, Pekanbaru, Indonesia \\ ${ }^{1}$ silviaekaputripku@gmail.com, ${ }^{2}$ otang.kurniaman@ lecturer.unri.ac.id
}

\begin{abstract}
ABSTRAK
Penelitian ini bertujuan untuk mengembangkan komik cerita rakyat "Asal Mula Desa Aliantan" dan mengetahui kelayakan komik cerita rakyat "Asal Mula Desa Aliantan" tersebut. Produk komik cerita rakyat ini dibuat menggunakan aplikasi Clip Studio Paint. Metode penelitian yang digunakan adalah model 4D terdiri dari empat tahapan yaitu Define (Pendefenisian). Design (Perancangan), Develop (Pengembangan), dan Disseminate (Penyebaran) dan hanya dibatasi sampai tahap tiga. Pengumpulan data dilakukan dengan menggunakan angket, instrumen penelitian yang digunakan telah melalui proses validasi dengan validator. Jenis data yang dihasilkan berupa data kuantitatif yang dianalisis menggunakan pedoman kriteria penilaian untuk menentukan kualitas produk. Hasil validasi dari para ahli menyatakan bahwa produk KOTARA (Komik Cerita Rakyat) Asal Mula Desa Aliantan untuk siswa Sekolah Dasar yang dikembangkan oleh peneliti sangat layak digunakan. Penilaian ahli desain produk dengan persentase rata-rata sebesar $91.66 \%$ dengan kategori sangat layak, penilaian ahli bahasa dengan persentase rata-rata $92.70 \%$ dengan kategori sangat layak, dan pengguna lapangan berdasarkan desain produk dengan persentase rata-rata $86.10 \%$ serta penilaian dari pengguna lapangan berdasarkan penggunaan bahasa dengan persentase $85.41 \%$ dengan kategori sangat layak.
\end{abstract}

Kata Kunci: komik cerita rakyat, sekolah dasar

\section{DEVELOPING KOTARA (KOMIK CERITA RAKYAT) "ASAL MULA DESA ALIANTAN" FOR ELEMENTARY SCHOOL STUDENTS}

\begin{abstract}
This research aimed to develop folklore comic "Asal Mula Desa Aliantan" and to find out if qualifications folklore comic is worthy. The folklore comic was made by application clip studio paint. The method in this study was a 4D model including define, design, develop, disseminate, and it was restricted to three steps. Data collecting used a questionnaire. The research instrument was validated by the experts. The type of data was quantitative which was analyzed by using assessment criteria guidelines for product quality. The validation from the expert found that using folklore comic "Asal Mula Desa Aliantan" for elementary school students was worthy. The average percentage from the design experts was $91.66 \%$ with the category of very feasible. The average percentage from the language experts was $92.70 \%$ with the category of very feasible. Then, the percentage from the users was $86.10 \%$ for the product design and $85.40 \%$ for the language use with the category of very feasible.
\end{abstract}

Keywords: folklore comic, elementary school

\begin{tabular}{|c|c|c|}
\hline Submitted & Accepted & Published \\
\hline 19 Agustus 2020 & 15 April 2021 & 23 November 2021 \\
\hline
\end{tabular}

\begin{tabular}{|l|l|l|l|l|}
\hline Citation & $:$ & Putri, S. E., \& Kurniaman, O. (2021). Pengembangan Kotara (Komik Cerita Rakyat) “Asal Mula Desa Aliantan” Untuk \\
& & $\begin{array}{l}\text { Siswa Sekolah Dasar. Jurnal PAJAR (Pendidikan dan Pengajaran), 5(6), 1550-1558. DOI : } \\
\text { http://dx.doi.org/10.33578/pjr.v5i6.8118. }\end{array}$ & \\
\hline
\end{tabular}

\section{PENDAHULUAN}

Komik juga didefenisikan bentuk kartun yang mengungkapkan karakter dan menerapkan suatu cerita dalam urutan yang erat hubungannya dengan gambar yang dirancang untuk memberikan hiburan kepada peserta didik, karena komik yang berupa kartun dapat menarik perhatian pembaca khususnya peserta didik (Daryanto, 2017). Komik merupakan media komunkasi visual yang unik karena menggabungkan teks dan gambar dalam bentuk yang kreatif serta mempunyai kekuatan untuk menyampaikan informasi secara populer dan mudah dimegerti (Walyuyanto, 2012).

Adapun kelebihan komik yaitu dapat memberi motivasi peserta didik selama proses belajar mengajar, komik terdiri dari gambargambar yang merupakan media yang dapat meningkatkan kuallitas pembelajaran, komik bersifat permanen, komik dapat membangkitkan 
minat membaca dan mengarahkan peserta didik untuk disiplin membaca khususnya bagi mereka yang tidak suka membaca, komik adalah bagian dari budaya yang popular (Wurianto, 2009).

Komik cerita rakyat adalah media pembelajaran visual yang berbentuk gambar dan telah tersusun dan disesuaikan tata letaknya. Gambar-gambar yang terdapat didalam komik disesuaikan dengan urutan peristiwa yang membentuk sebuah cerita rakyat. Dan didalam buku komik tersebut terdapat teks dan gambar yang disesuaikan dengan persitiwa yang terjadi disuatu daerah. Dengan gambar yang menarik pesan yang ada dalam buku komik tersebut dapat tersampaikan dengan baik oleh para pembaca.

Cerita rakyat adalah bentuk karya sastra yang di lisan kan dan terus berkembang dimasyarakat tradisional dari waktu ke waktu yang cukup lama dengan menggunakan kata klise (Danandjaja, 2013). Cerita rakyat adalah cerita yang dikembangkan secara lisan, cerita yang ada dalam masyarakat, cerita yang berkaitan dengan agama, sosial masyarakat dan juga tentang kepercayaan suatu masyarakat. Cerita yang diwariskan secara turun temurun. Cerita rakyat itu mempunyai keudukan dan fungsi yang sangat strategis dalam kehidupan masyarakat. Sebab itu dalam cerita rakyat mengandung nilai-nilai luhur terutama nilai-nilai karakter maupun ajaran moral (Suryanto, 2017). Gambar-gambar yang terdapat didalam komik dapat mengenalkan nilai-nilai karkater yang ada dalam sebuah cerita rakyat dan juga dapat membantu siswa dalam memahami cerita dan membangun daya imjinasi siswa.

Melalui cerita rakyat, generasi muda dapat diajarkan pendidikan karakter seperti nasionalisme, gotong royong, displin, mandiri, kerjasama, dan sebagainya. Cerita rakyat diciptakan untuk mempengaruhi pemikiran anak agar berperilaku sesuai dengan etika dan norma yang baik dalam masyarakat (Purwaningrum, 2019). Cerita rakyat tidak dapat dipisahkan dari dunia anak-anak karena dalam cerita rakyat memiliki imajinasi sehingga dapat membantu anak menambah nilai pengetahuan bagi anak serta nilai moral.

Tingkat pendidikan sekolah dasar merupakan masa-masa yang paling tepat untuk mengenalkan nilai-nilai karakter pada siswa.
Pendidikan dasar merupakan pendidikan lanjutan setelah pendidikan dari lingkungan keluarga , karakter siswa sangat berpengaruh terdapat lingkungan sekitar tempat siswa tinggal. Melalui pendidikan karakter diharapkan siswa mampu secara mandiiri menggunakan pengetahuannya, mengimplementasikan nilai-nilai karakter dalam kehidupan mereka sehari-hari (Khotimah, 2019). Nilai pendidikan karakter mengandung tiga unsur pokok yaitu mengetahui kebaikan, mencintai kebaikan, dan melakukan kebaikan. Selain tiga unsur pokok tersebut terdapat dua unsur moral dasar yang harus diberikan yaitu rasa hormat dan rasa tanggung jawab (Lickona, 2013).

\section{METODE PENELITIAN}

Penelitian ini adalah penelitian pengembangan yang menggunakan model $4 \mathrm{D}$ yang terdiri dari Pendefenisian, Perancangan, Pengembangan, Penyebaran (Thiagarjan, 2016). Penelitian pengembangan (development reseacrh) adalah metode penelitian yang digunakan untuk menghasilkan produk tertentu dan menguji keefektifan produk tersebut (Sugiyono, 2012). Penelitian pengembangan adalah suatu proses untuk mengembangkan suatu produk baru atau menyempurnalam produk yang sudah ada yang dapat dipertanggungjawabkan. Pada peneltian ini peneliti mengembangkan komik cerita rakyat "Asal Mula Desa Aliantan" untuk siswa sekolah dasar.

Pengembangan komik cerita rakyat "Asal Mula Desa Aliantan" ini menggunakan model 4D yang terdiri dari empat tahapan yaitu define, design, develop dan dessiminate. Jenis data yang digunakan adalah data kuantitatif berupa skor penilaian yang diberikan oleh validator terhadap komik cerita rakyat yang dikembangkan. Data hasil penelitian berupa hasil penilaian validasi yang dilakukan dengan 1 ahli media, 1 ahli bahasa, dan 2 orang guru sekolah dasar sebagai ahli lapangan. Penelitian ini tidak semua tahapan dilakukan hanya dibatasi pada tiga tahapan, karena peneliti hanya mengembangkan komik cerita rakyat saja untuk mengetahui hasil kelayakan produk yang dikembangkan.

Aspek penilaian yang dinilai oleh ahli dibuat dalam skala likert dengan skor 1-4. Dengan menggunakan skala ini dapat memberikan 
kebebasan bagi validator untuk memberikan penilaian terhadap produk yang dikembangkan. Komik cerita rakyat yang dikembangkan jika penilaian rata-rata validator dikategorikan layak dan sangat layak. Validasi media ditentukan oleh nilai rata-rata tiap aspek yang didapatkan dari validator dengan rumus :

Persentase $=\frac{\text { Skor yang diperoleh }}{\text { skor maksimum }} \times 100 \%$

Tabel 1. Presentase Kriteria Validitas Komik Cerita Rakyat

\begin{tabular}{ccc}
\hline No. & Interval rata-rata Presentase (\%) & Kategori respon \\
\hline 1. & $76-100$ & Sangat Layak \\
2. & $51-85$ & Layak \\
3. & $26-50$ & Tidak Layak \\
4. & $0-25$ & Sangat Tidak Layak \\
\hline
\end{tabular}

Sumber : Modifikasi,(Sugiyono, 2019)

\section{HASIL DAN PEMBAHASAN}

Validasi komik cerita rakyat "Asal Mula Desa Aliantan" dilakukan dengan 4 validator yaitu 1 ahli media, 1 ahli bahasa dan 2 orang guru sekolah dasar sebagai ahli lapangan. Pada proses validasi juga dilakukan perbaikan sesuai dengan saran dari para validator. Perbaikan komik cerita rakyat "Asal Mula Desa Aliantan" dapat berupa grafis gambar, tata bahasa dan lain sebagainya. Setelah melakukan revisi validator akan melakukan penilaian terhadap komik cerita rakyat sesuai dengan instrumen validasi komik cerita rakyat. Berikut adalah hasil validasi ahli media, ahli bahasa dan ahli lapangan untuk menilai kelayakan produk yang dikembangkan.

Tabel 2. Data Validasi Ahli Media

\begin{tabular}{cccc}
\hline No. & Aspek Penilaian & $\begin{array}{c}\text { Persentase Rata-Rata } \\
\text { Aspek }\end{array}$ & Kategori Validasi \\
\hline 1. & Desain Komik & $91.66 \%$ & Sangat Layak \\
\hline
\end{tabular}

Data kelayakan Desain Produk yang digunakan dalam komik cerita rakyat "Asal Mula Desa Aliantan". Dalam aspek desain komik terdapat sembilan indikator yang digunakan untuk menilai desian produk yang dikembangkan oleh peneliti, pada aspek ini memperoleh rata-rata $91.66 \%$ dengan kategori sangat layak. Berdasarkan analisis dan informasi dari aspek Desain Komik yang dirancang dan dinilai oleh validator, maka perancangan produk yang dikembangkan yaitu Komik Cerita Rakyat "Asal Mula Desa Aliantan" untuk siswa sekolah dasar. Sangat layak digunakan untuk siswa sekolah dasar.

Tabel 3. Data Validasi Ahli Bahasa

\begin{tabular}{cccl}
\hline No. & Aspek Penilaian & $\begin{array}{c}\text { Persentase } \\
\text { Rata-rata } \\
\text { Aspek }\end{array}$ & Kategori Validasi \\
\hline 1. & Kesederhanaan & $87.5 \%$ & Sangat Layak \\
2. & Penekanan & $91.66 \%$ & Sangat Layak \\
3. & Keseimbangan & $100 \%$ & Sangat Layak \\
4. & Keterpaduan & $91.66 \%$ & Sangat Layak \\
& Rata-rata kelayakan & $\mathbf{9 2 . 7 0 \%}$ & Sangat Layak
\end{tabular}


Dari data kelayakan bahasa yang digunakan dalam komik cerita rakyat "Asal Mula Desa Aliantan" terdapat 4 aspek yang terdiri dari beberapa indikator yang dinilai oleh validator ahli bahasa. Aspek Kesederhanaan, terdapat dua indikator yang digunakan untuk mengembangan produk, pada aspek ini memperoleh persentase skor $87.5 \%$ dengan kategori sangat layak. Berdasarkan data ini memberikan informasi bahwa Bahasa yang digunakan dalam komik cerita rakyat "Asal Mula Desa Aliantan" dari aspek kesederhanaan bahasa yang digunakan dapata mengembangkan kemampuan logis siswa, dan bahasa menggunakan resapan bahasa dalam kehidupan sehari-hari.

Dalam aspek penekanan, terdapat tiga indikator yang digunakan untuk menilai penekanan bahasa yang digunakan untuk komik cerita rakyat "Asal Mula Desa Aliantan" untuk Siswa Sekolah Dasar, pada aspek ini memperoleh persentase skor 91.66\% dengan kategori sangat layak. Berdasarkan data ini memberikan informasi bahwa penekanan struktur kalimat sesuai dengan tingkat penguasaan kognitif siswa, kalimat yang digunakan jelas dan mudah dipahami siswa SD dan menggunakan kalimat yang positif.

Dalam aspek keseimbangan, terdapat dua indikator yang digunakan untuk menilai keseimbangan bahasa yang digunakan untuk komik cerita rakyat "Asal Mula Desa Aliantan" untuk Siswa Sekolah Dasar yang dikembangkan, pada aspek ini memperoleh skor sebesar 100\% dengan kategori sangat layak. Berdasarkan data ini memberikan informasi bahwa cerita rakyat yang disajikan menarik minat siswa untuk membaca dan alur cerita yang digunakan dalam komik mudah dipahami siswa.

Dalam aspek keterpaduan, terdapat tiga indikator yang digunakan untuk menilai keterpaduan bahasa yang digunakan untuk komik cerita rakyat "Asal Mula Desa Aliantan" untuk Siswa Sekolah Dasar yang dikembangkan. Pada aspek ini memperoleh skor $91.66 \%$ dengan kategori sangat layak. Berdasarkan data ini memberikan informasi bahwa keterpaduan alur cerita yang digunakan sesuai dengan taraf berpikir siswa SD, cerita yang disajikan dalam komik lengkap dan jelas dan informasi yang disampaikan dalam cerita jelas.

Rata-rata kelayakan bahasa yang digunakan untuk kelayakan komik cerita rakyat “Asal Mula Desa Aliantan” untuk Siswa Sekolah Dasar secara keseluruhan memperoleh persentase $92.70 \%$ dengan kategori sangat layak.

Tabel 4. Data Validasi Desain Produk Pengguna Lapangan

\begin{tabular}{cccc}
\hline No. & Aspek Penilaian & Persentase Rata-Rata Aspek & $\begin{array}{c}\text { Kategori } \\
\text { Validasi }\end{array}$ \\
\hline 1. & Desain Komik & $86.10 \%$ & Sangat Layak \\
\hline
\end{tabular}

Data kelayakan Desain Produk yang digunakan dalam komik cerita rakyat "Asal Mula Desa Aliantan". Dalam aspek desain komik terdapat sembilan indikator yang digunakan untuk menilai kelayakan desain produk yang dikembangkan oleh peneliti, pada aspek ini memperoleh rata-rata $91.66 \%$ dengan kategori sangat layak. Berdasarkan data ini memberikan informasi bahwa desain komik tersusun rapi dan sistematis, gambar yang digunakan pada cover menggambarkan ini, ukuran gambar yang digunakan proposional, ukuran dan bentuk komik praktis dan fleksibel, tata letak antara panel satu dengan panel yang lainnya rapi dan dapat membantu siswa dalam memahami alur cerita, kepraktisan komik mudah dibawa, susunan cerita pada komik rapi, tipe dan ukuran huruf komik sesuai dan mudah di baca oleh siswa SD dan komik cerita rakyat memberikan pembelajaran yang mengandung nilai-nilai karakter. 
Jurnal PAJAR (Pendidikan dan Pengajaran)

Volume 5 Nomor 6 November | ISSN Cetak : 2580 - 8435 | ISSN Online : 2614 - 1337

DOI : http://dx.doi.org/10.33578/pjr.v5i6.8118

Tabel 5. Data Validasi Bahasa Pengguna Lapangan

\begin{tabular}{llcl}
\hline No. & Aspek Penilaian & Persentase Rata-rata Aspek & \multicolumn{1}{c}{ Kategori Validasi } \\
\hline 1. & Kesederhanaan & $81.25 \%$ & Sangat Layak \\
2. & Penekanan & $87.5 \%$ & Sangat Layak \\
3. & Keseimbangan & $81.25 \%$ & Sangat Layak \\
4. & Keterpaduan & $91.66 \%$ & Sangat Layak \\
& Rata-rata Kelayakan & $\mathbf{8 5 . 4 1 \%}$ & Sangat Layak \\
\hline
\end{tabular}

Data kelayakan komik cerita rakyat "Asal Mula Desa Aliantan" untuk Siswa Sekolah Dasar terdapat empat aspek yang terdiri dari beberapa indikator yang telah dilakukan penilaian oleh validator. Aspek kesederhanaan terdapat dua indikator yang digunakan untuk menilai kesederhanaan bahasa yang digunakan dalam produk yang dikembangkan, pada aspek ini memperoleh persentase skor $81.25 \%$ dengan kategori sangat layak. . Berdasarkan data ini memberikan informasi bahwa penekanan struktur kalimat sesuai dengan tingkat penguasaan kognitif siswa, kalimat yang digunakan jelas dan mudah dipahami siswa SD dan menggunakan kalimat yang positif.

Dalam aspek penekanan, terdapat tiga indikator yang digunakan untuk menilai penekanan bahasa yang digunakan untuk komik cerita rakyat "Asal Mula Desa Aliantan" untuk Siswa Sekolah Dasar, pada aspek ini memperoleh persentase rata-rata $87.5 \%$. Berdasarkan data ini memberikan informasi bahwa penekanan struktur kalimat sesuai dengan tingkat penguasaan kognitif siswa, kalimat yang digunakan jelas dan mudah dipahami siswa SD dan menggunakan kalimat yang positif.
Dalam aspek keseimbangan, terdapat dua indikator yang digunakan untuk menilai keseimbangan bahasa yang digunakan untuk komik cerita rakyat "Asal Mula Desa Aliantan" untuk Siswa Sekolah Dasar yang dikembangkan, pada aspek ini memperoleh rata-rata $81.25 \%$. Berdasarkan data ini memberikan informasi bahwa cerita rakyat yang disajikan menarik minat siswa untuk membaca dan alur cerita yang digunakan dalam komik mudah dipahami siswa.

Dalam aspek keterpaduan, terdapat tiga indikator yang digunakan untuk menilai keterpaduan bahasa yang digunakan untuk komik cerita rakyat "Asal Mula Desa Aliantan" untuk Siswa Sekolah Dasar yang dikembangkan. Pada aspek ini memperoleh rata-rata $91.66 \%$. Berdasarkan data ini memberikan informasi bahwa keterpaduan alur cerita yang digunakan sesuai dengan taraf berpikir siswa SD, cerita yang disajikan dalam komik lengkap dan jelas dan informasi yang disampaikan dalam cerita jelas.

Rata-rata kelayakan bahasa yang digunakan untuk kelayakan komik cerita rakyat "Asal Mula Desa Aliantan" untuk Siswa Sekolah Dasar secara keseluruhan memperoleh persentase $85.41 \%$ dengan kategori sangat layak.

Tabel 6. Gambar Sebelum dan Sesudah Divalidasi

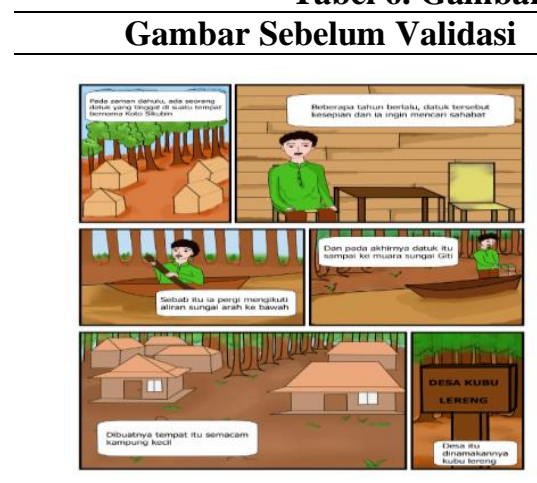
Gambar Sesudah Validasi

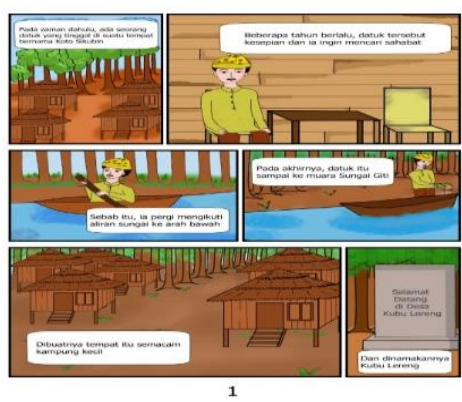


Jurnal PAJAR (Pendidikan dan Pengajaran)

Volume 5 Nomor 6 November | ISSN Cetak : 2580 - 8435| |ISSN Online : 2614 - 1337

DOI : http://dx.doi.org/10.33578/pjr.v5i6.8118

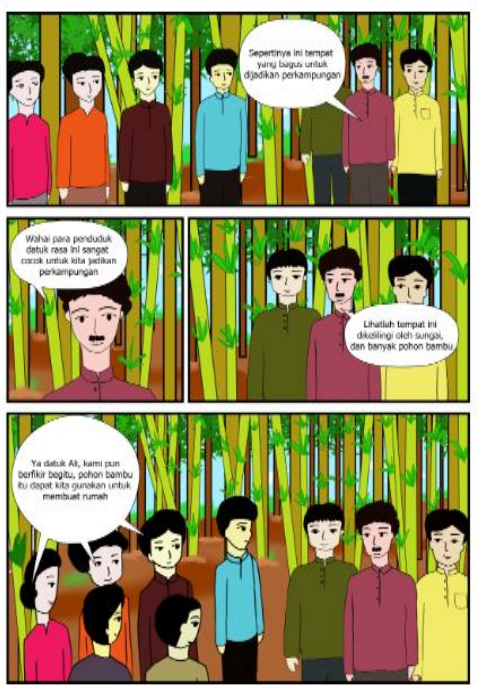

Tujuan dilakukannya revisi gambar pada komik cerita rakyat "Asal Mula Desa Aliantan" yang peneliti kembangkan untuk siswa sekolah dasar sehingga layak digunakan. Perbaikan yang dilakukan pada halaman 1 yaitu bentuk rumah yang disajikan pada gambar seperti tenda, setelah dilakukannya revisi bentuk rumah dirubah dengan bentuk atap dari bahan daun kelapa dan rumah tampak seperti rumah panggung, pada halaman 1
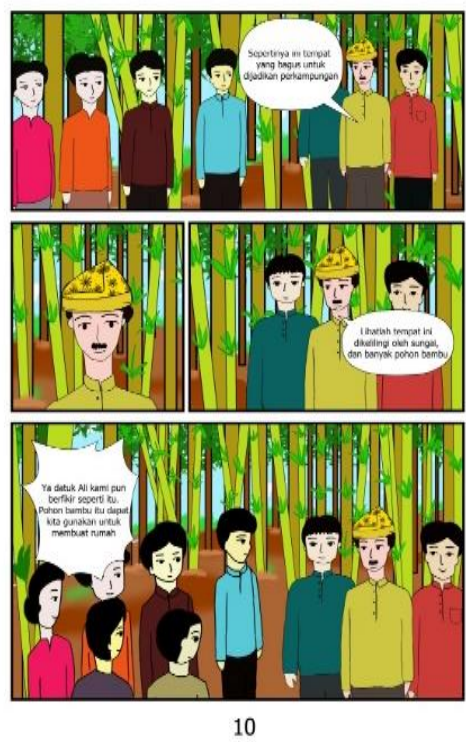

juga warna air yang semulanya berwarna coklat dan setelah direvisi berubah menjadi warna biru, dan pada halaman 1 yang awalnya tokoh dalam cerita tersebut tidak menggunakan tanjak setelah direvisi berubah menjadi menggunakan tanjak. Pada halaman 10 yang awalnya bentuk panel dari komik berbentuk bulat dan setelah direvisi berbentuk zig-zag.

Tabel 7. Cerita Sebelum dan Sesudah validasi

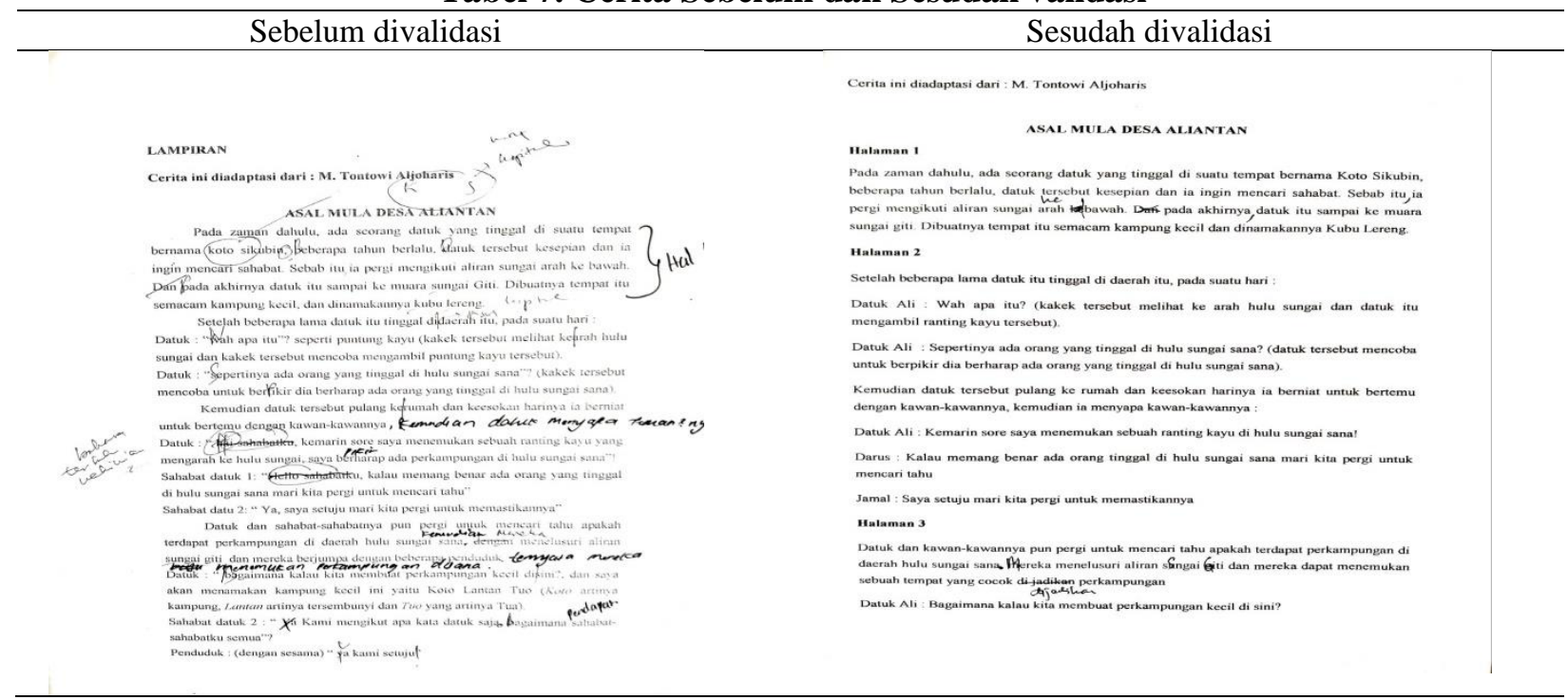


Jurnal PAJAR (Pendidikan dan Pengajaran)

Volume 5 Nomor 6 November | ISSN Cetak : 2580 - 8435| | ISSN Online : 2614 - 1337

DOI : http://dx.doi.org/10.33578/pjr.v5i6.8118
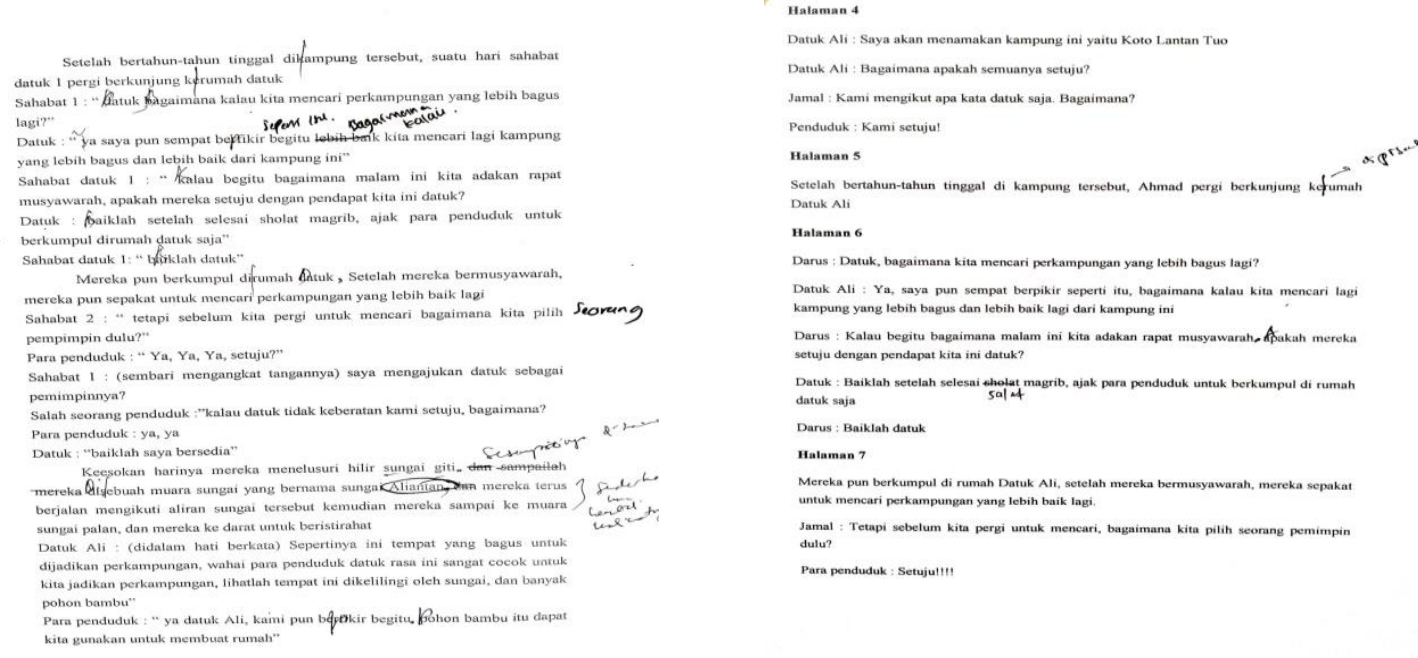

Dan mercka pun menctap dan membangun perkampungan difana, setelah bertahun-talun lamanya perkampungant tersebut pun semakin berkembang das terbentuklah suatu kebudayaan selempat dengan berbagai macam suku yang ada menurut cerita orang kampung tersebut terdupat cmpat macam suku yang ad yaitu suku Pitopang, Suku Melayu dan Suku Thiang serta-Mandamione Jikayo. Penduduk 1: "setelah sekian lama kita tinegal dikini, tetapi kita belum mempunyal pemimpin adat

kan musyawarah?"

enduduk 2:" ya,

Penduduk 3 " "yaa, saya setuju " "enduduk 4 :" kala
musyawarahnya"?

Penduduk $1,2,3$ : "baikla "

Penduduk 2 :

Penduduk 4 : "ide yang bagus"

Di

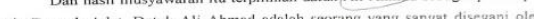

a

Olch sebab itu hingea nama koto atau kampung itu bernama ALIANT ANY Nama $^{2}$

ini de denut dori pangkal nama pimpinan adat yang kemudian disatukan denge

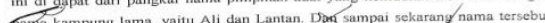
crabadikan.

jo

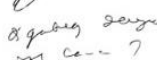

Darus : Saya mengajukan Datuk Ali sechagai pemimpinny

Penduduk : Kalau datuk tidak keberatan kami setuju, bagaimana

Para Penduduk: Ya, ya, ya....!!!

Datuk Ali: Baiklah saya bersedia

Hataman 9

Keesokan harinya mereka menelusuri hilir sungai giti, sesampainya di muara sungai, mereka terus berjalan mengikuti aliran sungai tersebut, sesampainya di muara sungai palan, merek turun ke darat untuk beristirahat

Halaman 10

Datuk Ali : Sepertinya ini tempat yang bagus untuk dijadikan perkampungan, wahai para

Penduduk : Ya datuk Ali kami pun berpikir seperti itu. Pohon bambu itu dapat kita gunakar

Hataman 11

Dan mercka pun menetap dan membangun perkampungan di sana. Setelah bertahun-tahun

setempat dengan berbagai suku yang ad

Halaman 12

Menurut cerita orang kampung tersebut terdapat empat macam suku yang ada yaitu suku

Penduduk 1 : Setelah sekian lama tinggal di sini, tetapi kita belum mempunyai pemimpin

Penduduk 2 : Benar sekali, bagaimana kalau kita adakan musyawarah untuk memilih

Penduduk 4 : Kalau begitu, gimana besok malam setelah shotar isya kita adakan musyawarah Penduduk 1: Baiklah

Halaman 13

Dari hasil musyawarah terpilihlah Datuk Ali Ahmad sebagai pemimpin adat pucuok ad

Halaman 14

Datuk Ali Ahmad adalah seorang yang sangat discgani oleh masyarakat setempat la juga seorang pemberani, kuat luar dalam serta bijaksana. Oleh sebab itu nama Koto atau Kampung itu bernama Aliantan Nama inı diambil dari pangkal nama pemimpin adat kemudian disatukan dengan nama kampung lama, yaitu Ali dan Lantan. pán Gampai sekarang nama tersebut terabadikar 
Tujuan dilakukannya revisi penulisan pada komik cerita rakyat "Asal Mula Desa Aliantan yang peneliti kembangkan agar penulisan serta tanda baca yang terdapat pada komik sesuai untuk siswa Sekolah dasar, bahasa yang digunakan dalam komik mudah dipahami oleh siswa sekolah dasar, struktur kalimat yang digunakan juga mudah dipahami.

\section{Pembahasan}

Berdasarkan maksud dan tujuannya penelitian ini digolongkan sebagai penelitian pengembangan yaitu penelitian yang bermaksud mengembangan sebuah produk, produk yang dikembangkan berupa komik cerita rakyat "Asal Mula Desa Aliantan" untuk Siswa Sekolah Dasar. Penelitian pengembangan adalah strategi yang pas untuk memperbaiki praktik. Penelitian pengembangan bertujuan untuk mengembangan suatu produk baru atau menyempurnakan produk yang telah ada sebelumnya.

Penelitian pengembangan merupakan rangkaian proses atau langkah-langkah dalam mengembangan suatu produk yang efektif dan merupakan bahan-bahan pembelajaran, media, strategi, pembelajaran yang digunakan untuk sekolah dan bukan menguji teori. Pada penelitian ini peneliti mengembangkan komik cerita rakyat "Asal Mula Desa Aliantan" untuk siswa sekolah dasar. Dimana tujuan penelitian ini yaitu mengenalkan nilai-nilai karkater yang terdapat dalam komik cerita rakyat "Asal Mula Desa Aliantan", bahwasannya terdapat nilai-nilai yang dapat diambil dari cerita rakyat tersebut.

Model pengembangan yang digunakan yaitu model penelitian 4D, yang terdiri dari Pendefenisian, Perancangan, Pengembangan, Penyebaran (Thiagarjan, Pengembangan Buku Pengayaan Konteks NanoSelilosa untuk membangun Literasi Siswa SMA, 2016). Yang terdiri dari 4 tahap yaitu, pendefenisian (define), perancangan (design), pengembangan (develop) dan penyebaran (disseminate). Penelitian yang dilakukan oleh peneliti dibatasi hanya melakukan tiga tahap.

Penelitian ini dimulai dengan tahap pendefenisian (define), pada tahap ini yang dilakukan peneliti yaitu menganalisis cerita rakyat, cerita rakyat yang diambil oleh peneliti yaitu cerita rakyat dari daerah Rokan Hulu dengan judul “Asal Mula Desa Aliantan"(diadaptasi dari M. Tontowi Aljoharis) cerita rakyat yang diambil di sebuah digital book kemudian peneliti mengadaptasi cerita rakyat tersebut.

Setelah melakukan analisis cerita rakyat, tahap selanjutnya adalah tahap design atau perancangan. Tahap design merupakan tahap merancang produk KOTARA (Komik Cerita Rakyat) "Asal Mula Desa Aliantan" dengan membuat dialog, selanjutnya peneliti menganalisis nilai-nilai karkater yang terdapat dalam cerita rakyat tersebut dan didapatkan dari cerita tersebut nilai yang dapat diambil yaitu nilai karkater gotong royong, dimana terdapatnya bentuk kerjasama, bahu-membahu dan persahabatan. Kemudian peneliti juga membuat konsep komik, tokoh, format dan ukuran, desain gambar, teknik pengerjaan, warna dan tipografi.

Tahap ketiga adalah tahap pengembangan (development), pada tahap ini peneliti melakukan validasi produk kepada 1 orang ahli desain produk, 1 orang ahli bahasa, 2 orang pengguna lapangan. Berdasarkan hasil validasi komik cerita rakyat "Asal Mula Desa Aliantan" Ahli desain produk memperoleh persentase skor $91.66 \%$ dengan kategori sangat layak, hasil validasi ahli bahasa memperoleh persentase skor $92.70 \%$ dengan kategori sangat layak, hasil validasi pengguna lapangan berdasarkan kelayakan desain produk memperoleh persentase $86.10 \%$ dengan kategori sangat layak, dan hasil validasi pengguna lapangan berdasarkan kelayakan bahasa $85.41 \%$ dengan kategori sangat layak. Sehingga berdasarkan hasil tersebut secara keseluruhan KOTARA (Komik Cerita Rakyat) Asal Mula Desa Aliantan untuk Siswa Sekolah Dasar yang dikembangkan oleh peneliti sangat layak digunakan pada siswa Sekolah Dasar.

Pengembangan komik cerita rakyat ini juga sangat erat hubungannya dengan dunia anakanak. Hal tersebut di karenakan agar lebih mempermudah anak dalam memahami isi sebuah bacaan yang mereka baca. Dengan membaca KOTARA (Komik Cerita Rakyat) anak-anak juga dapat mengenali nilai-nilai karakter yang terdapat dalam sebuah cerita rakyat. Penggunaan bahasa dalam KOTARA (Komik Cerita Rakyat) ini juga menggunakan bahasa yang sederhana dan mudah 
dipahami anak. Peneliti berharap setelah adanya pengembangan KOTARA (Komik Cerita Rakyat) dan anak-anak telah membacanya agar dapat mengetahui asal usul dari sebuah nama desa "Asal Mula Desa Aliantan" dan juga dapat melestarikan cerita rakyat yang ada di daerahnya sebagai pengenalan nilai karakter pada sebuah cerita rakyat.

\section{SIMPULAN DAN REKOMENDASI}

Hasil validasi dari para ahli menyatakan bahwa produk KOTARA (Komik Cerita Rakyat) Asal Mula Desa Aliantan untuk siswa Sekolah Dasar yang dikembangkan oleh peneliti sangat layak digunakan. Penilaian ahli desain produk dengan persentase rata-rata sebesar $91.66 \%$ dengan kategori sangat layak, penilaian ahli bahasa dengan persentase rata-rata $92.70 \%$ dengan kategori sangat layak, dan pengguna lapangan berdasarkan desain produk dengan persentase ratarata $86.10 \%$ serta penilaian dari pengguna lapangan berdasarkan penggunaan bahasa dengan persentase $85.41 \%$ dengan kategori sangat layak.

Peneliti selanjutnya perlu dilakukan penelitian lebih lanjut untuk memperoleh data, masukan dan saran yang lebih banyak untuk mendapatkan hasil yang maksimal. Guru dapat menggunakan penelitian ini sebagai masukan dalam mengembangan komik cerita rakyat untuk siswa sekolah dasar.

\section{DAFTAR PUSTAKA}

Danandjaja. (2013). Cerita Rakyat Masyarakat Rambah Kabupaten Rokan Hulu Provinsi Riau, 1.

Daryanto. (2017). Kontribusi Pengembangan Media Komik IPA Bermuatan Karakter pada Materi Daya Alam untuk Siswa MI/SD. Jurnal Pendidikan Dasar Islam, 5(1), 189-195.

Khotimah. (2019). Implementasi Program Penguatan Pendidikan Karakter (PPK) Melalui Kegiatan 5s di Sekolah Dasar. Jurnal Ilmiah Kependidikan, 7(2), 28-35.

Lickona. (2013). Analisis Nilai Pendidikan Karakter Dalam Cerita Rakyat Seluma. Jurnal Korpus, 7(1), 40-49.

Purwaningrum, I. A. (2019). Menggali Nilai Pendidikan Karakter Berbasis Kearifan
Lokal Melalui Cerita Rakyat. Jurnal Pendidikan Bahasa dan Sastra Indonesia, 7(2), 44-52.

Sugiyono. (2012). METODE PENELITIAN (Pendekatan Kualitatif, Kuantitatif, dan $R \& D)$. Bandung: Alfabeta.

Sugiyono. (2019). METODE PENELITIAN (Pendekatan Kulitatif, Kuantitatif, dan $R \& D)$. Bandung: Alfabeta.

Suryanto, E. (2017). Model Pendidikan Karakter Berbasis Pembelajaran Apresiasi Cerita Rakyat Dengan Menggunakan Media Wayang Kancil. Jurnal Pendidikan Bahasa dan Sastra, 2.

Thiagarjan. (2016). Pengembangan Buku Pengayaan Konteks NanoSelilosa untuk membangun Literasi Siswa SMA. Universitas Pendidikan Indonesia, 4.

Walyuyanto. (2012). Pengembangan Media Komik Bergambar Materi Sistem Saraf untuk Pembelajaran yang Menggunakan Strategi PQ4R. Jurnal Of Innovative Education, 10(4), 20-30.

Wurianto. (2009). Pengembangan Media Komik untuk Efektifitas dan Meningkatkan Hasil Belajar Kognitif Materi Perubahan Lingkungan Fisik. Jurnal Pendidikan Surya Edukatif (JPSE), 11(4), 20-35. 